\title{
Epidermal growth factor and epidermal growth factor receptor in the ovary of the domestic cat (Felis catus)
}

\author{
F. Göritz, K. Jewgenow and H. H. D. Meyer \\ Institute for Zoo Biology and Wildlife Research, Alfred-Kowalke-Strasse 17, 10315 Berlin, Germany
}

\begin{abstract}
Identification of epidermal growth factor (EGF) and its distribution in the ovary were examined with an immunohistochemical technique using a polyclonal rabbit antibody against mouse EGF. A combination of HPLC and enzymeimmunoassay was elaborated to quantify EGF in different compartments of the feline ovary. In addition, EGF receptors were localized in ovarian cryostat sections with a new ligand-histochemical technique using biotinylated EGF for labelling. Epidermal growth factor was present in theca interna cells, in specific aggregations of interstitial gland cells located next to tertiary follicles, in smaller, single cells of the ovarian cortex, and in the corpus luteum. The strongest EGF-positive reaction was found in vacuolized cells of the interstitium and in theca interna cells of large tertiary follicles rich in cytoplasm. The strictly cellular localization of the EGF-antibody reaction suggests the synthesis of EGF in these cells. Specific binding sites of EGF were present on granulosa cells of secondary and tertiary follicles and on interstitial gland cells. The EGF-binding capacity of granulosa cells of the cumulus oophorus was greater than that of the mural granulosa cells. Granulosa cells of atretic follicles showed a lower or no affinity for staining. In conclusion, we suggest that EGF plays an important role in ovarian folliculogenesis in cats.
\end{abstract}

\section{Introduction}

Peptide growth factors such as epidermal growth factor (EGF), transforming growth factor $\alpha$ (TGF- $\alpha$ ), TGF- $\beta$ and insulin-like growth factor (IGF-I) are suspected to play a crucial role in ovarian folliculogenesis. They are produced locally within the ovary and are involved in the regulation of ovarian processes (Gospodarowicz and Bialecki, 1979; Skinner et al., 1987; May et al., 1988; Adashi, 1993; Mulheron and Schomberg, 1993) such as cell proliferation, differentiation, and steroidogenesis. The mitogenic effect of EGF has been shown on cultured bovine granulosa and luteal cells (Gospodarowicz et al., $1977 a, b)$. The influence of EGF on ovarian function is uncertain. However, there is increasing evidence that EGF regulates cellular activity of granulosa cells by stimulation of FSH receptor expression and progesterone production (Serta and Seibel, 1993; Murray et al., 1993; Luciano et al., 1994) as well as inhibition of FSH-induced LH receptors, inhibin secretion and aromatase activity (Dunkel $e$ t al., 1994). In vitro maturation studies demonstrated a positive effect of EGF on the cytoplasmic maturation of mouse (Phipps et al., 1992), human (Das et al., 1991), pig (Reed et al., 1993) and bovine (Lorenzo et al., 1994) oocytes. Human EGF and mouse EGF share $70 \%$ similarity in their sequence of 53 amino acids, induce nearly identical biological effects and are highly interspecies crossreactive (Gregory, 1975; Carpenter and Cohen, 1979). In this regard, nothing is known about feline EGF. The effect of EGF is mediated by binding to a specific glycoprotein receptor, the

Received 24 May 1995.
EGF-receptor (EGF-R). EGF and TGF- $\alpha$ act upon the same receptor. Ligand binding to the extracellular domain of EGF-R leads to generation of signals mediating the cellular reaction, autophosphorylation of the intracellular domain, and internalization of the ligand-receptor complex. The EGF-R has been detected by ligand-binding assays on ovarian tissue homogenates and isolated granulosa cells of rats (Jones et al., 1982).

Immunohistological studies determining the location of growth factors are helpful in clarifying the relationships of paracrine and autocrine mechanisms of regulation in vivo. The distribution of EGF in hamster ovaries has been investigated by Roy and Greenwald (1990) and localization of both EGF and EGF-R in follicular and stromal compartments of the human ovary has been determined by Maruo et al. (1993). The cell-specific simultaneous expression of EGF and EGF-R suggests an autocrine mode of EGF action.

The aim of the present study was to detect the EGF and EGF-binding sites in feline ovaries to assist our work on in vitro growth of oocytes and preantral follicles of cats (Jewgenow and Pitra, 1993; Jewgenow and Göritz, 1995). Biochemical identification of EGF in different morphological regions of ovaries from domestic cats was performed by mechanical dissociation, protein clean-up and development of a specific EGF-enzyme immunoassay. In addition, we tried to differentiate the location of EGF in the feline ovary by using the peroxidase-antiperoxidase technique on semithin tissue sections and to demonstrate histochemical EGF-receptor binding sites by exposing biotinylated EGF on ovarian cryostat sections. 


\section{Materials and Methods}

\section{Tissue collection and preparation}

Ovaries were collected from domestic cats that were undergoing ovariohysterectomy at a local animal clinic. All ovaries were selected during the breeding season with three or four active corpora lutea. Upon removal from the cat, the ovaries were immediately placed into Hank's balanced salts solution (HBSS; Sigma Chemie GmbH, Deisenhofen) with $1 \%(\mathrm{v} / \mathrm{v})$ antibiotic-antimycotic solution (Sigma Chemie $\mathrm{GmbH}$ ) and were either processed within $2-5 \mathrm{~h}$, or fixed in $3 \%(\mathrm{v} / \mathrm{v})$ buffered formalin with addition of $1 \%(\mathrm{v} / \mathrm{v})$ glutaraldehyde (E. Merck, Darmstadt) and 3\% (w/v) saccharose (Carl Roth $\mathrm{GmbH} \& \mathrm{Co}$, Karlsruhe). The histological ligand binding assay was performed on shock-frozen ovaries, embedded before plunging into liquid nitrogen in Tissue tec (Sigma Chemie $\mathrm{GmbH}$ ).

\section{Tissue homogenization}

Whole ovaries ( $n=5$ ), ovaries after dissection of corpora lutea $(n=3)$ and isolated corpora lutea $(n=10)$ were washed separately three times in homogenization buffer ( $10 \mathrm{mmol} \mathrm{PBS} \mathrm{l}^{-1}$, with $10 \mathrm{mmol}$ EDTA $^{-1}, 10 \mathrm{mmol}$ Imidazol $\mathrm{l}^{-1}, 1 \mathrm{mmol}$ phenylmethylsulphonyl fluoride $\mathrm{l}^{-1}, \mathrm{pH} 7.4,20$ trypsin inhibitor units aprotinin $1^{-1}$, E. Merck Darmstadt), pooled, homogenized on ice $\left(10 \mathrm{mg}\right.$ tissue $\mathrm{ml}^{-1}$ homogenization buffer) $5 \times 20 \mathrm{~s}$ with an Ultraturrax and centrifuged for $25 \mathrm{~min}$ at $20000 \mathrm{~g}$. The supernatants were collected and ultracentrifuged for $1 \mathrm{~h}$ at $100000 \mathrm{~g}$. The high speed supernatants were collected and represented the cytosol. After repeated filtration (Millipore, $0.22 \mu \mathrm{m}$ pore size), the protein concentration of the cytosol was determined (Smith et al., 1985), using BSA as the standard.

\section{High pressure liquid chromatography}

The cytosols of pooled, homogenized samples were cleaned up and fractionated ( $20 \mathrm{~s}$ per fraction) by chromatography with two ultraspherogel columns (3 USG 11 and 22 USG 216, Beckman). Sample volume was $200 \mu \mathrm{l}$, flow rate $1 \mathrm{ml} \mathrm{\textrm {min } ^ { - 1 }}$ and the total running time $25 \mathrm{~min}$. Chromatography buffer $\left(60\right.$ mmol disodium hydrogen phosphate $1^{-1}, \mathrm{pH}$ 7.2) was used as the liquid phase. The retention time of EGF was determined with a pure EGF standard (10 $\mu \mathrm{g}$ mouse EGF $\mathrm{ml}^{-1}$ water, receptor grade; Sigma, E 1264) by photometrical detection of the protein peak.

\section{Enzyme-linked immunoassay}

Microtitre plates (Nunc, Roskilde) were incubated with $1 \mu \mathrm{g}$ sheep anti-rabbit IgG per $100 \mu \mathrm{l}$ disodium hydrogen carbonate buffer $\left(50 \mathrm{mmol} \mathrm{l}^{-1}, \mathrm{pH} 9.6\right)$ per well for $2 \mathrm{~h}$ at room temperature. The plates were decanted and the remaining protein binding sites were saturated with $300 \mu \mathrm{l}$ assay buffer (40 mmol disodium hydrogen phosphate $\mathrm{l}^{-1}, 160 \mathrm{mmol}$ sodium chloride $\mathrm{l}^{-1}, 0.1 \%(\mathrm{w} / \mathrm{v})$ BSA (Serva, No. 11926), $\mathrm{pH}$ 7.2) per well for $45 \mathrm{~min}$ at room temperature. After decantation, plates were stored at $-20^{\circ} \mathrm{C}$ until use. All subsequent steps were performed using assay buffer. After they had thawed at room temperature, the plates were washed four times with $0.05 \mathrm{~mol}$ Tween $80 \mathrm{l}^{-1}$. The wells were incubated with $100 \mu \mathrm{l}$ standard or fractionated ovarian tissue homogenates plus $50 \mu \mathrm{l}$ polyclonal rabbit anti-mouse EGF antibody (Sigma, No. E-2635, at dilution 1:100 000) at $4^{\circ} \mathrm{C}$. The high interspecies crossreactivity of EGF was used because no species specific anti-EGF antibody was available. After $16 \mathrm{~h}, 2 \mathrm{ng}$ biotinylated EGF (Boehringer No. 1141317) per well was added and the plates were incubated for $2 \mathrm{~h}$ at $4^{\circ} \mathrm{C}$. The microtitre plates were washed four times and incubated with $37.5 \mathrm{ng}$ Streptavidin-horseradish peroxidase conjugate (Boehringer) per well for $15 \mathrm{~min}$ at $4^{\circ} \mathrm{C}$. After washing the plates four times, $150 \mu \mathrm{l}$ enzyme-substrate solution (A: $1.25 \mathrm{mmol} 3,3^{\prime}, 5,5^{\prime}$ tetramethylbenzidine $\mathrm{l}^{-1}, 50 \mathrm{mmol}$ citric acid $\mathrm{I}^{-1}, 40 \mathrm{ml}$ dimethylsulfoxide $\mathrm{l}^{-1}, \mathrm{pH} \mathrm{2.4;} \mathrm{B:} 11 \mathrm{mmol}$ hydrogen peroxide-urea $\mathrm{I}^{-1}$ (E. Merck), $0.1 \mathrm{~mol}$ disodium hydrogen phosphate $\mathrm{I}^{-1}, 50 \mathrm{mmol}$ citric acid $1^{-1}, 0.1 \mathrm{ml}$ Kathon $\mathrm{I}^{-1}$ (Röhm \& Haas, Croydon), pH 5.0; A and B were mixed $I: I \mathrm{~V}: \mathrm{V}$ and used immediately) was added and incubated for $40 \mathrm{~min}$ at $25^{\circ} \mathrm{C}$. The reaction was stopped with $50 \mu \mathrm{l} 2 \mathrm{~mol}$ $\mathrm{H}_{2} \mathrm{SO}_{4} 1^{-1}$ and extinction was measured at $450 \mathrm{~nm}$. Mouse EGF (3.125-1600 pg, receptor grade; Sigma, E 1264) was used for the calibration curve in each assay. The assay was characterized by repeatedly $71 \%$ EGF recovery and a $50 \%$ relative binding in the presence of $25 \mathrm{pg}$ EGF. The anti-EGF antibody used did not crossreact with human TGF- $\alpha(<0.1 \%)$.

\section{Immunohistochemistry}

For immunohistochemical detection of EGF, a modification of the peroxidase-antiperoxidase technique (Sternberger $e t$ al., 1969) was used. Sections $(1 \mu \mathrm{m})$ of plastic-embedded (Technovit 8100 , Heraeus-Kulzer, Wehrheim/Ts.) ovaries $(n=10)$ were exposed to $1.5 \%(\mathrm{v} / \mathrm{v})$ hydrogen peroxide in methanol for $30 \mathrm{~min}$ to inhibit the endogenous peroxidase activity. The sections were washed three times in assay buffer and incubated in normal goat serum (1:5 v:v in PBS; Sigma Chemie GmbH) at room temperature to block nonspecific binding of primary antibodies. All subsequent washing steps and dilution of antibodies were carried out in assay buffer. Incubation with the primary antibody (rabbit-antimouse EGF, polyclonal, working dilution 1:1000; Sigma, E 2635) was followed by successive addition of the secondary (bridging) antibody (goat-antirabbit IgG, working dilution 1:30; Sigma) and rabbit peroxidase-antiperoxidase soluble complex (Sigma; 1:300, $30 \mathrm{~min}$ ). All incubations with antibodies were carried out in a humidified chamber at $37^{\circ} \mathrm{C}$. The specific antigen locations were detected by incubation with the enzyme substrate solution $0.8 \mathrm{mmol}$ $3,3^{\prime}$ diaminobenzidine $\mathrm{l}^{-1}$; Sigma, D $8001,50 \mathrm{mmol}$ Tris- $\mathrm{HCl}$ $1^{-1}, 0.15 \%(\mathrm{v} / \mathrm{v})$ hydrogen peroxide) for $10 \mathrm{~min}$ at room temperature. All sections were counterstained with haematoxylin, embedded with Canada balsam (Sigma, C 1794) and examined by light microscopy.

Adjacent control sections were subjected to the same method, with the exception that the primary antibody to EGF was replaced by rabbit nonimmune serum (Sigma) at the same dilution as the specific antibody and also by assay buffer. No positive staining was observed in the negative controls. 


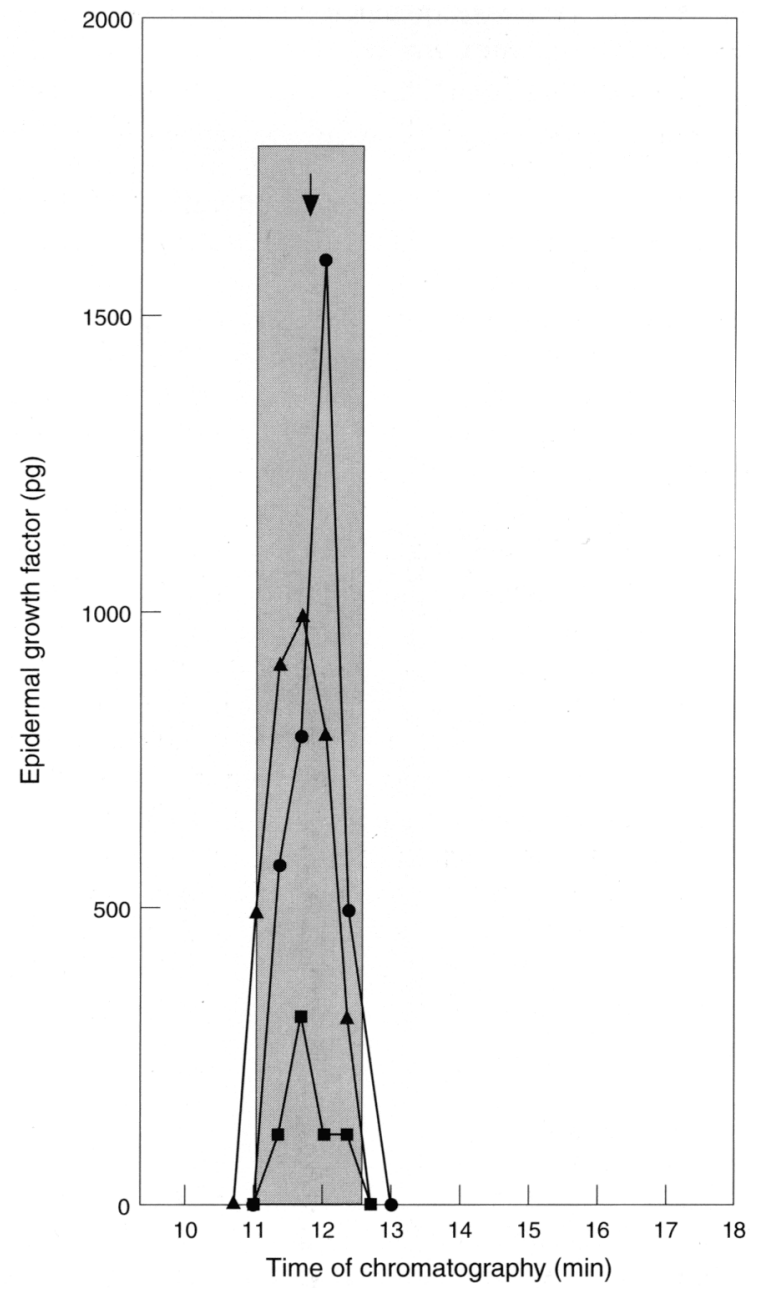

Fig. 1. Detection and measurement of epidermal growth factor (EGF)

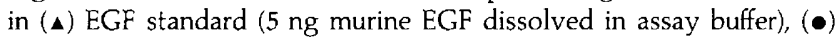
cytosol of feline ovarian homogenate with addition of $5 \mathrm{ng}$ mouse EGF (two positive controls) and ( cytosol of feline ovarian homogenate using an enzymeimmunoassay after clean-up and fractionation (20 s per fraction) with gel chromatography. The base-line represents the negative control (assay buffer). The maximum of the UV-detected EGF peak ( $2 \mu \mathrm{g}$ mouse EGF dissolved in water) occurred after chromatography for $11.5 \mathrm{~min}$ (arrow). The EGF peak width was 1.2 min (hatched area).

\section{Histological EGF-receptor ligand binding assay}

EGF-receptor binding using biotinylated EGF (Boehringer Mannheim) was performed on $10 \mu \mathrm{m}$ ovarian cryostat sections $(n=4)$. After fixation in acetone for $2 \mathrm{~min}$ at $4^{\circ} \mathrm{C}$, the ovarian tissue sections were washed four times with assay buffer and incubated overnight with $100 \mathrm{ng}$ biotinylated EGF $\mathrm{ml}^{-1}$ assay buffer at $4^{\circ} \mathrm{C}$ in a humid chamber. The specificity of the EGFreceptor binding assay was investigated by successive addition of unlabelled EGF $\left(1 \mu \mathrm{g} \mathrm{ml}^{-1}, 10 \mu \mathrm{g} \mathrm{ml}^{-1}, 100 \mu \mathrm{g} \mathrm{ml}^{-1}\right.$ assay buffer) to displace the biotinylated EGF from the EGF receptor. After washing, the sections were exposed to $1.5 \%(\mathrm{v} / \mathrm{v})$ hydrogen peroxide in methanol for $30 \mathrm{~min}$ to inhibit the endogenous peroxidase activity and washed again three times in assay buffer. The sections were then incubated for $15 \mathrm{~min}$ at room temperature with Streptavidin-horseradish peroxidase conjugate $\left(100 \mu \mathrm{g} \mathrm{ml}^{-1}\right.$ assay buffer; Boehringer). After repeated washing, the specific biotinylated EGF-binding sites were visualized by incubation with enzyme-substrate solution for $10 \mathrm{~min}$ at room temperature.

\section{Results}

\section{Biochemical detection of EGF in the ovary}

EGF was detected in cat ovaries using an enzymeimmunoassay after clean-up and fractionation with high performance gel chromatography. EGF standard ( 5 ng mouse EGF, receptor grade; Sigma; dissolved in assay buffer); ovarian homogenate with addition of $5 \mathrm{ng}$ EGF; and ovarian homogenate were tested (Fig. 1).

In the two positive control samples, EGF was detected in fraction numbers $32-39$ and in the ovarian preparation, in fraction numbers 33-38. No EGF was detected in the negative control (assay buffer). The position of the enzymeimmunoassay peaks correlated with the UV-detected peak maximum (11.5 min) and peak width (1.2 min) of EGF standard (Fig. 1).

The amount of EGF was measured in whole ovary, ovary without corpus luteum and isolated corpus luteum (Table 1) to evaluate whether active corpora lutea are involved in providing EGF. The concentrations of EGF were 7.7 and $195.1 \mathrm{pg} \mathrm{mg}^{-1}$ protein in the ovarian homogenate and active corpus luteum, respectively. No EGF was detected in the ovarian tissue without corpus luteum. Therefore, a further separation of this tissue (ovary without corpus luteum) into granulosa cell, primary and secondary follicle fractions was not considered worthwhile because the expected EGF content of these components is below the amount detectable by enzymeimmunoassay.

\section{Histology}

EGF. Immunohistological staining of semithin sections of feline ovaries showed EGF to be localized in three different types of cell (Table 2). The strongest EGF positive reaction was found in the active corpus luteum (Fig. 2a). Small and large luteal cells were immunostained. Aggregations of vacuolized cells of the interstitium, which were rich in cytoplasm and located close to tertiary follicles, and some theca interna cells of large tertiary follicles showed strong positive staining (Fig. $2 \mathrm{~b}$ ). In the ovarian cortex, a few smaller, unvacuolized single cells were highly positive for EGF (Fig. 2c).

EGF receptor. The EGF receptor was detected by histological ligand binding assay. A competitive displacement of biotinylated EGF was possible by successive addition of unlabelled EGF. A 1000-fold excess of unlabelled EGF resulted in complete displacement of biotinylated EGF (Fig. 3a-d). The binding sites of biotinylated EGF on the different ovarian cell types are summarized (Table 2). Specific binding sites for EGF were present only on granulosa cells of primary, secondary and tertiary follicles and on interstitial gland cells. The highest EGF binding capacity was shown on exterior granulosa cells of large 
Table 1. Epidermal growth factor (EGF) content in pooled cytosols of whole ovaries $(n=5)$, ovaries without corpora lutea $(n=3)$ and isolated, active corpora lutea $(n=10)$

\begin{tabular}{lccc}
\hline Tissue & $\begin{array}{c}\text { Amount of } \\
\text { protein } \\
\left(\mathrm{mg} \mathrm{ml}^{-1}\right)\end{array}$ & $\begin{array}{c}\text { Absolute amount } \\
\text { of EGF } \\
\left(\mathrm{pg} \mathrm{ml}^{-1}\right)\end{array}$ & $\begin{array}{c}\text { Relative amount } \\
\text { of EGF } \\
\text { (pg ml }\end{array}$ \\
\hline $\begin{array}{l}\text { Ovary } \\
\text { Ovary without corpus luteum }\end{array}$ & 7.5 & 57.5 & 7.7 \\
Corpus luteum & 5.1 & $\mathrm{nd}^{\mathrm{b}}$ & - \\
\hline
\end{tabular}

antegral of EGF containing fractions.

bot detectable.

Table 2. Intraovarian localisation of epidermal growth factor (EGF) and density of EGF-binding sites

\begin{tabular}{|c|c|c|c|c|c|}
\hline \multirow[b]{3}{*}{ Ovarian cell type } & \multirow[t]{3}{*}{ EGF } & \multicolumn{4}{|c|}{ EGF receptor } \\
\hline & & \multicolumn{4}{|c|}{ Biotinylated EGF + EGF } \\
\hline & & $1+0 \mu g$ & $I+10 \mu g$ & $1+100 \mu g$ & $1+1000 \mu \mathrm{g}$ \\
\hline \multicolumn{6}{|l|}{ Primary follicle } \\
\hline Granulosa & - & + & - & - & - \\
\hline \multicolumn{6}{|l|}{ Secondary follicle } \\
\hline \multicolumn{6}{|l|}{ Granulosa } \\
\hline Internal layer & - & + & - & - & - \\
\hline Exterior layers & - & + & + & + & - \\
\hline \multicolumn{6}{|l|}{ Tertiary follicle } \\
\hline Cumulus granulosa cells & - & + & + & + & - \\
\hline \multicolumn{6}{|l|}{ Mural granulosa } \\
\hline Internal layers & - & + & + & - & - \\
\hline Exterior layers & - & + & - & - & - \\
\hline Theca interna cells & + & - & - & - & - \\
\hline Corpus luteum & + & - & - & - & - \\
\hline Interstitial gland cells & + & + & + & - & - \\
\hline
\end{tabular}

- , Not detected; + , detected.

secondary (Fig. 3e) follicles and cumulus cells of tertiary follicles (Fig. 3f). Granulosa ceils of atretic follicles showed minor or no staining (Fig. 3a, e).

\section{Discussion}

To our knowledge, this is the first description of EGF in felids. We have examined the presence of EGF in feline ovaries by two different means: localization and measurement of EGF, and detection of EGF-binding sites. The simultaneous estimation of EGF and EGF-binding sites allows speculation to be made regarding the regulatory role of EGF in folliculogenesis in cats.

EGF, a $6 \mathrm{kDa}$ polypeptide, is one of the best known and well characterized growth factors (Cohen and Savage, 1979). Mouse EGF can promote proliferation of many mammalian cells (Barnes and Sato, 1980). The phylogenetically highly conserved amino acid sequence is expressed not only in mammalian, but also in avian species. A polyclonal rabbit antibody raised against recombinant human EGF has been used for detection of this protein in chicken ovaries (Onagbesan et al., 1994). Therefore, it is not surprising that the antibody raised against mouse EGF crossreacts with a protein in cat ovary. All enzymeimmunoassay EGF-positive peaks of feline ovarian proteins and mouse EGF standard were superimposed and corresponded with the retention time detected by UV (11.5 s) and the peak width $(1.2 \mathrm{~min})$ of the mouse EGF. These results are evidence for the antibody specificity. Furthermore, it can be concluded that the feline EGF is also a $6 \mathrm{kDa}$ polypeptide. In addition, quantitative estimation of EGF was possible by integrating the EGF peaks of the tissues analysed. The limit of sensitivity of the enzymeimmunoassay was $31.2 \mathrm{pg} \mathrm{EGF} \mathrm{ml}^{-1}$. EGF ( $5 \mathrm{ng}$ ) in assay buffer resulted in the detection of $3.74 \mathrm{ng}$ after purification by gel chromatography in fraction number $32-38$, which indicates an EGF recovery of $71 \%$. The presence of EGF in cat ovaries indicates a possible role for this growth factor in ovarian regulatory processes. The separation of the corpus luteum by dissection and subsequent quantitative 

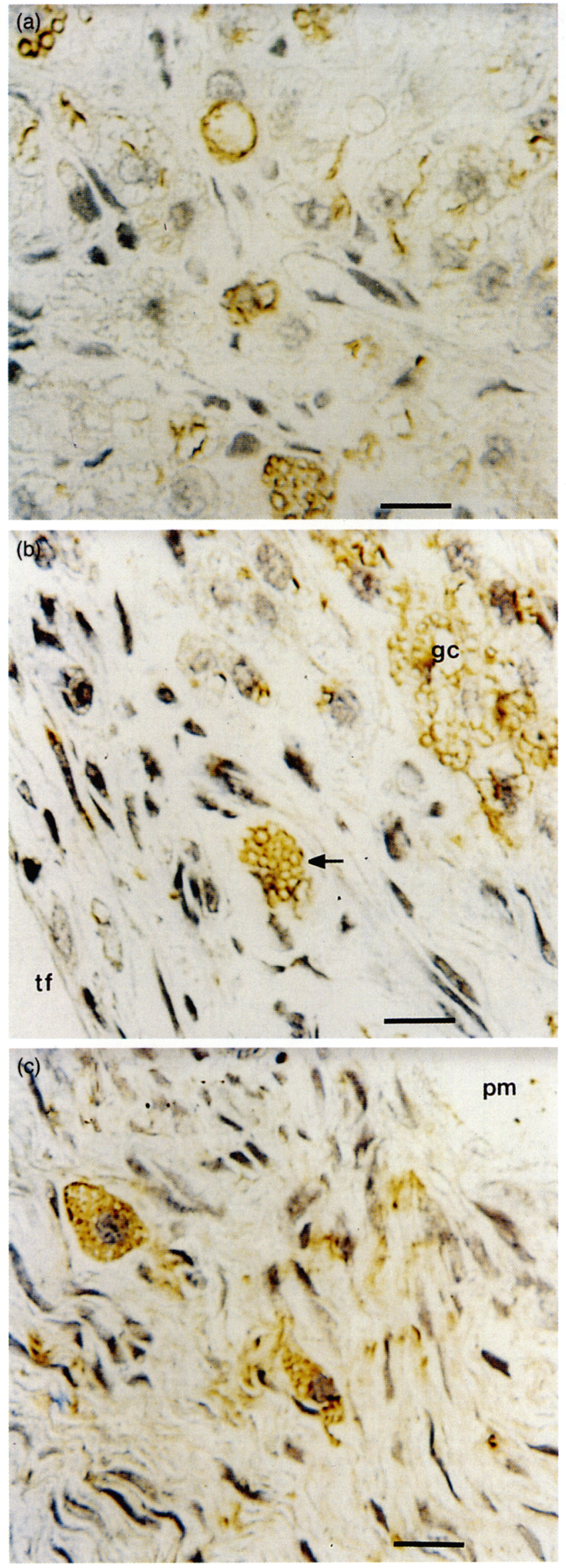

analysis showed the highest concentrations of EGF in the active corpus luteum, whereas the content in other parts of the ovary was not measurable.

The function of the corpus luteum is to produce progesterone and other steroid hormones. Changes in cellular concentrations of EGF and immunologically detected EGF-R in the corpus luteum during the course of the luteal phase appear to be consistent with the change in the steroidogenic capacity of the corpus luteum throughout the luteal phase in humans (Maruo et al., 1993). It has been shown in cultured granulosa cells that EGF not only exerts stimulatory effects on FSH receptor induction and $\mathrm{FSH}$-induced progesterone production, but also exerts inhibitory effects on FSH-induced oestradiol production (Feng et al., 1987; Roy and Greenwald, 1990). The cycle of the cat is characterized by repeated increases in oestradiol concentrations and low progesterone. After mating, the progesterone concentration increases and is still high for 28-35 days in pseudopregnant animals or until parturition in pregnant animals (Tsutsui and Stabenfeldt, 1993). Therefore, the corpus luteum is active in pseudopregnant animals for a relatively long period and EGF could be involved in retaining progesterone production and oestradiol inhibition. In immunohistochemical studies, EGF was localized in the corpus luteum, although EGF-binding sites were not detected. The EGF-R may be impaired for two possible reasons. Our receptor-binding test detects only unsaturated EGF-R and the high content of EGF in the corpus luteum implies that almost all receptors are already occupied. However, the high concentration of EGF could have induced downregulation of EGF-R. Owing to high EGF concentrations in the corpus luteum and impaired EGF-R detection, we cannot exclude an autocrine role for EGF in the corpus luteum.

Even though EGF was not measurable in the cytosol of ovarian tissue without a corpus luteum, the immunohistochemical estimation of EGF and EGF-R has helped to clarify the role of EGF in folliculogenesis in cats. In agreement with results in humans (Maruo et al., 1993), feline primordial follicles express neither EGF nor EGF-R. The granulosa cells of primary follicles weakly bind biotinylated EGF. A ten-fold EGF concentration displaces biotinylated EGF-staining by competition for binding sites. The anti-EGF antibody used detected some solitary EGF-positive cells in the ovarian cortex near primordial follicles. We hypothesize that these cells are premature interstitial glands, inducing the transformation of primordial (resting) follicles into primary (growing) follicles by paracrine EGF impact on granulosa cells. The nature of these solitary EGF-containing cells is uncertain.

The receptor distribution in granulosa cells of secondary and tertiary follicles is characterized by a differentiation of the

Fig. 2. Immunohistological detection of epidermal growth factor (EGF) in $1 \mu \mathrm{m}$ sections of plastic-embedded ovaries using the peroxidase-anti-peroxidase method. The brown products represent positive immunoreactivity. (a) EGF-positive reaction of luteal cells. (b) EGF in vacuolized interstitial glandular cell (gc) close to tertiary follicle ( $\mathrm{t}$ ) and in same large theca interna cells (arrow) of tertiary follicles. (c) EGF-positive reaction of solitary interstitial cells, not vacuolized and localized in the ovarian cortex close to primordial follicle (pm). Scale bar represents $10 \mu \mathrm{m}$. 

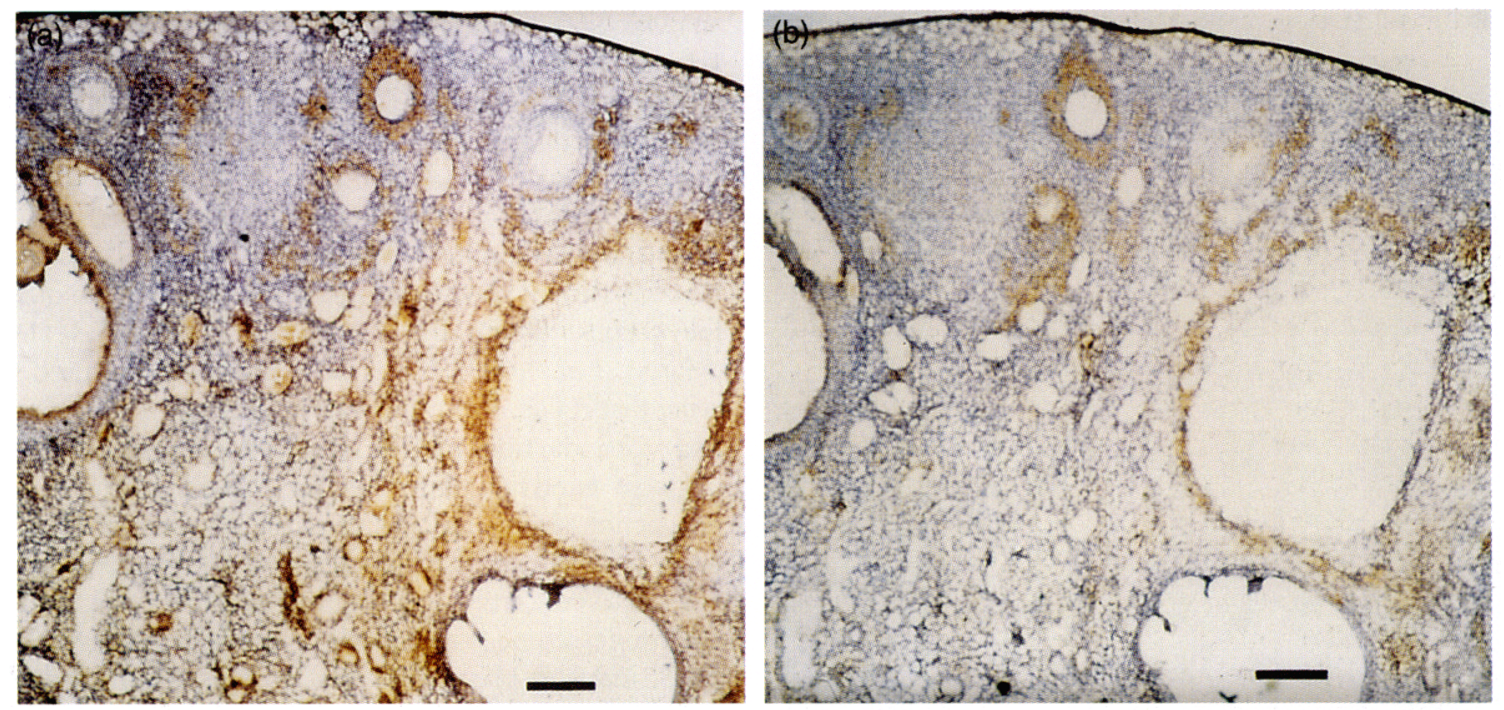

(c)
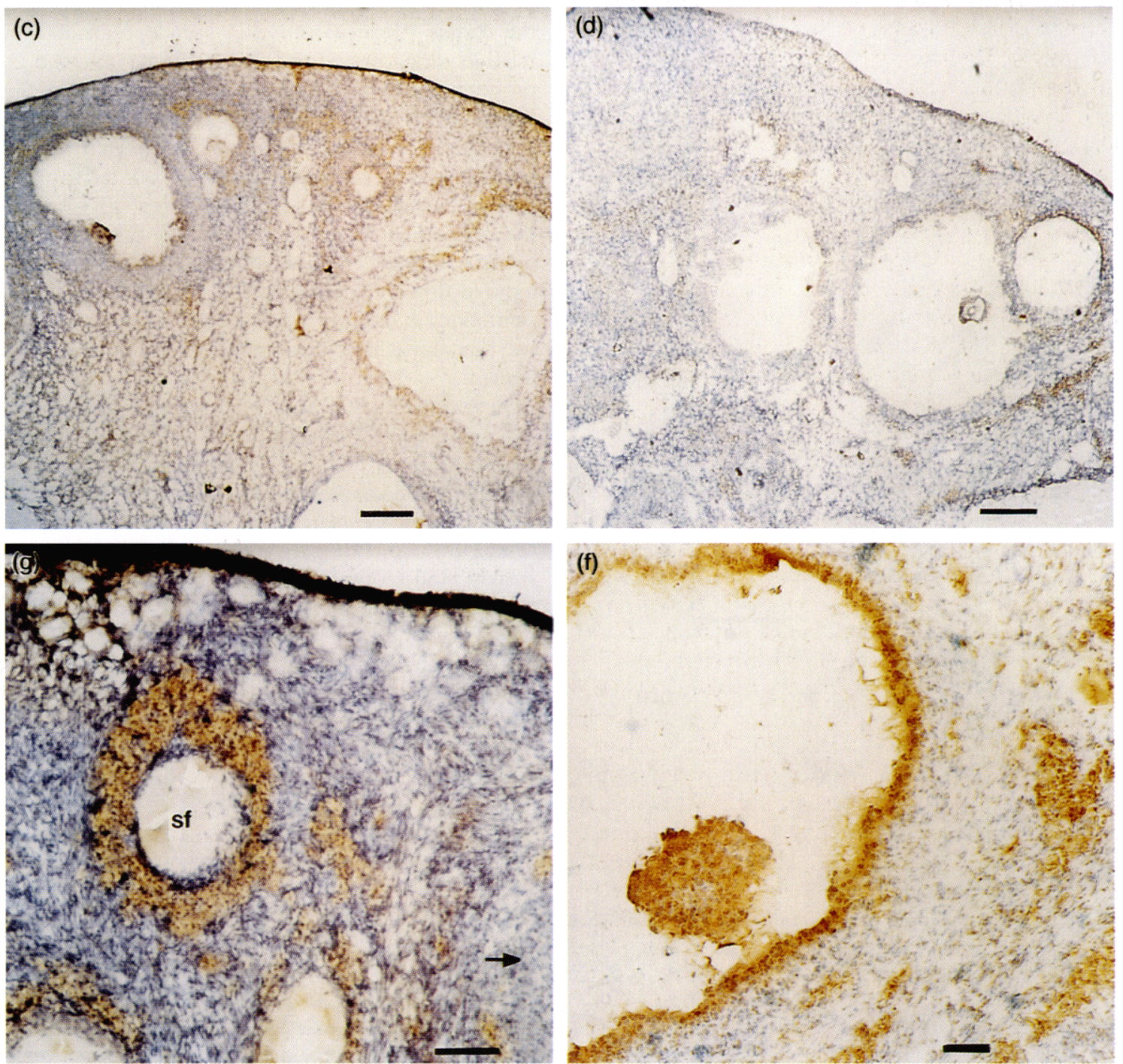

Fig. 3. Epidermal growth factor (EGF) binding sites (brown products) detected by a histological ligand binding assay with biotinylated EGF on ovarian cryostat sections ( $10 \mu \mathrm{m}$ thick). (a-d) Competitive displacement of biotinylated EGF by successive addition of unlabelled EGF (a, $1+0$; b, $1+10 ; c, 1+100 ; d, 1+1000 \mu$ g biotinylated EGF/EGF). (e) Granulosa cells of large secondary follicles (sf) highly stained for EGF receptors on exterior cell layers. Granulosa cells of atretic follicle (arrow) showed minor or no staining. (f) Tertiary follicle with cumulus oophorus (brown spherical structure in the antrum); cumulus cells and internal layers of mural granulosa cells showed very intensive EGF-receptor staining. In a-d, scale bar represents $300 \mu \mathrm{m}$; e, $100 \mu \mathrm{m} ; \mathrm{f}, 80 \mu \mathrm{m}$. 
internal and external layers of granulosa. While the internal granulosa of secondary follicles expresses a low amount of receptors with displacement of biotinylated EGF in the presence of ten-fold excess of EGF, binding is suppressed only after the addition of a 1000-fold excess of unlabelled EGF in the external layer.

During the growth phase from primary to secondary follicle, the oocyte grows in size and forms the zona pellucida. Even the interior granulosa cells are involved in these tremendous morphological and biochemical changes of oocytes by maintaining close contact through cytoplasmic projections (Salustri et al., 1993). In addition, the granulosa cells acquire high-affinity receptors for FSH and steroid hormones. Granulosa proliferation is stimulated by the synergistic influence of oestrogens and FSH (Fritz and Speroff, 1982). Over a period of several days, the follicular cells undergo rapid division increasing from about $100-4000$ to more than 50000 cells (Wassarman, 1988). The localization of EGF-R in the granulosa layers appears to be an expression of the different functions necessary during the growth period (Hurst et al., 1993). The interaction between the oocyte and follicle cells requires fully differentiated granulosa cells at the same time as proliferation is occurring.

In addition, somatic cells in the adjacent interstitial tissue differentiate into theca cells and form the external cellular envelope of the follicle. The theca interna of tertiary follicles contains many EGF-positive cells. Semithin sections $(1-2 \mu \mathrm{m})$ allow good differentiation of cell types. All the EGF-positive cells are big and vacuolized, independent of their localization in theca interna, interstitial gland or corpus luteum. Immunohistological detection of EGF-R was not possible because all EGF-R-antibodies examined were not crossreactive in cats or did not work in histological sections. Therefore, a histological ligand binding assay was performed to detect EGF-R after preincubation with a labelled ligand.

EGF-R identification was performed on cryosections ( $10 \mu \mathrm{m})$ and, consequently, the cellular localization was more difficult than in semithin tissue sctions. However, some spatial differences between EGF and EGF-R expression were observed. EGF-R is located in the mural layer of the granulosa and in the cumulus oophorus. There is some staining of the interstitial gland, but no staining of the theca interna.

These results confirm other immunohistological studies, where the location of EGF was in the theca, but not in granulosa cells, while the EGF-R was found in both cell types (Scurry et al., 1994). In contrast to the results reported by Maruo et al. (1993), who described an autocrine regulation of EGF in human antral follicles exclusively, our findings suggest autocrine and paracrine impact of EGF. The paracrine regulation of EGF in tertiary follicles could be as follows: EGF is produced in theca interna and interstitial cells and interacts with granulosa and cumulus cells. EGF modulates the intraovarian gonadotrophin effects by preovulatory inhibition of oestradiol secretion and enhancement of progesterone production in granulosa cells (Murray et al., 1993). EGF enhances cumulus expansion and nuclear maturation (Reed et al., 1993; Lorenzo et al., 1994). In addition, it inhibits granulosa cell apoptosis, the cellular mechanism of atresia (Tilly et al., 1992; Luciano et al., 1994). We have described comparable results on in vitro cultivation of feline preantral follicles (Jewgenow and
Göritz, 1995). The addition of EGF to the culture medium has a structural supporting effect (less denudation) and results in a reduced percentage of atretic follicle cells and in an increase of intact germinal vesicle.

We suggest that EGF plays an important role in ovarian folliculogenesis in cats. During the growth phase, it acts as a mitogenic factor inducing granulosa cell proliferation, whereas in antral follicles, it regulates granulosa cell differentiation and maturation of oocytes.

The authors thank C. Talsness for the correction of the English in the manuscript.

\section{References}

Adashi EY (1993) The intraovarian insulin-like growth factor system. In The Ovary pp 319-336 Eds EY Adashi and PCK Leung. Raven Press, New York

Barnes D and Sato G (1980) Methods of growth of cultured cells in serum-free medium Analyfical Biochemistry 102 225-270

Carpenter G and Cohen S (1979) Epidermal growth factor Annual Review of Biochemistry 48 193-216

Cohen S and Savage CR, Jr (1979) Recent studies on the chemistry and biology of epidermal growth factor, part II Recent Progress in Hormone Research 30 $55 \mathrm{I}-574$

Das K, Stout LE, Hensleigh HC, Tagatz GE, Phipps WR and Leung BS (1991) Direct positive effect of epidermal growth factor on the cytoplasmatic maturation of mouse and human oocytes Fertility and Sterility 55 1000-1004

Dunkel L, Tilly JL, Shikone T, Nishimori K and Hsueh AJW (1994) Folliclestimulating hormone receptor expression in the rat ovary: increases during prepubertal development and regulation by the opposing actions of transforming growth factor $\beta$ and $\alpha$ Biology of Reproduction 50 940-948

Feng P, Knecht M and Catt K (1987) Hormone control of epidermal growth factor receptors by gonadotropins during granulosa cell differentiation Endocrinology $1201121-1126$

Fritz MA and Speroff L (1982) The endocrinology of the menstrual cycle: the interaction of folliculogenesis and neuroendocrine mechanisms Fertility and Sterility $38509-529$

Gospodarowicz D and Bialecki H (1979) Fibroblast and epidermal growth factors are mitogenic agents for cultured granulosa cells of rodent, porcine and human origin Endocrinology 104 757-764

Gospodarowicz D, Ill CR and Birdwell CR (1977a) Effects of fibroblast and epidermal growth factor on ovarian cell proliferation in vitro. I. Characterisation of the response of granulosa cells to FGF and EGF Endocrinology 100 $1108-1120$

Gospodarowicz D, Ill CR and Birdwell CR (1977b) Effects of fibroblast and epidermal growth factor on ovarian cell proliferation in vitro. II. Proliferative response of luteal cells to FGF but not EGF Endocrinology 100 1121-1128

Gregory $\mathbf{H}$ (1975) Isolation and structure of urogastrone and its relationship to epidermal growth factor Nature $257325-327$

Hurst BS, Zacur HA, Schlaff WD, Damewood MD and Berkowitz GD (1993) The effect of epidermal growth factor in human granulosa cells varies with follicle size Journal of Endocrinological Investigation 16 143-145

Jewgenow K and Göritz F (1995) The recovery of preantral follicles from ovaries of domestic cats and their characterization before and after cultivation Journal of Animal Reproduction Science 39 285-297

Jewgenow K and Pitra C (1993) Hormone-controlled culture of secondary follicles of domestic cats Theriogenology 39 527-535

Jones PBC, Welsh TH and Hsueh AJW (1982) Regulation of ovarian progestin production by epidermal growth factor in cultured rat granulosa cells Journal of Biological Chemistry 25711 268-11 273

Lorenzo PL, Illera MJ, IIlera JC and Illera M (1994) Enhancement of cumulus expansion and nuclear maturation during bovine oocyte maturation in vitro by the addition of epidermal growth factor and insulin-like growth factor 1 Journal of Reproduction and Fertility 101 697-701

Luciano AM, Pappalardo A, Ray C and Peluso JJ (1994) Epidermal growth factor inhibits large granulosa cell apoptosis by stimulating progesterone synthesis 
and regulating the distribution of intracellular free calcium Biology of Reproduction 51 646-654

Maruo T, Ladines-Llave CA, Samota T, Matsuo H, Manalo AS, Ito H and Mochizuki M (1993) Expression of epidermal growth factor and its receptor in the human ovary during follicular growth and regression Endocrinology 132 924-931

May JV, Frost JP and Schomberg DW (1988) Differential effect of epidermal growth factor, somatomedin-C/insulin like growth factor I, and transforming growth factor- $\beta$ on porcine granulosa cell desoxyribonucleic acid synthesis and cell proliferation Endrocrinology 123 168-179

Mulheron GW and Schomberg DW (1993) The intraovarian transforming growth factor. In The Ovary pp 337-362 Eds EY Adashi and PCK Leung. Raven Press, New York

Murray JF, Downing JA, Evans G, Findlay JK and Scaramuzzi RJ (1993) Epidermal growth factor acts directly on the sheep ovary in vivo to inhibit oestradiol-17 beta and inhibin secretion and enhance progesterone secretion Journal of Endocrinology 137 253-264

Onagbesan M, Gullick W, Woolveridge I and Peddie MJ (1994) Immunohistological localization of epidermal growth factor receptors, epidermal-growthfactor-like and transforming-growth-factor- $\alpha$-like peptides in chicken ovarian follicles Journal of Reproduction and Fertility 102 147-153

Phipps DK, Hensleigh WR and Tagatz GE (1992) Epidermal growth factor in human follicular fluid stimulates mouse oocyte maturation in vitro Fertility and Sterility 57 895-901

Reed ML, Estrada JL, Illera MJ and Petters RM (1993) Effects of epidermal growth factor, insulin-like growth factor-I, and dialyzed porcine follicular fluid on porcine oocyte maturation in vitro Joumal of Experimental Zoology $26674-78$

Roy SK and Greenwald GS (1990) Immunohistochemical localization of epidermal growth factor-like activity in the hamster ovary with a polyclonal antibody Endocrinology 126 1309-1317
Salustri A, Hascall VC, Camaioni A and Yanagishita M (1993) Oocyte granulosa cell interaction system. In The Ovary pp 209-225 Eds EY Adashi and PCK Leung. Raven Press, New York

Scurry JP, Hamand KA, Astley SB, Leake RE and Wells M (1994) Immunoreactivity of antibodies to epidermal growth factor, transforming growth factor alpha and beta, and epidermal growth factor receptor in the premenopausal ovary Pathology 26 130-133

Serta RT and Seibel MM (1993) The influence of epidermal growth factor on progesterone production by human granulosa-luteal cells in culture Human Reproduction 8 1005-1010

Skinner MK, Lobb D and Dorrinton JH (1987) Ovarian theca/interstitial cells produce an epidermal growth factor-like substance Endocrinology 121 1892-1899

Smith PK, Krohn RI, Hermanson GT, Mallia K, Gartner FH, Provenzano MD, Fujimoto EK, Goeke NM, Olson BJ and Klenk DC (1985) Measurement of protein using bicinchoninic acid Analytical Biochemistry 150 76-85

Sternberger LA, Hardy PH, Jr, Cuculis JJ and Meyer HG (1969) The unlabeled antibody enzyme method of immunohistochemistry, preparation and properties of soluble antigen-antibody complex (horseradish peroxidaseantihorseradish peroxidase) and its use in identification of spirochetes Journal of Histochemistry and Cytochemistry 18 315-333

Tilly JL, Billg H, Kowalski KI and Hsueh AJ (1992) Epidermal growth factor and basic fibroblast growth factor suppress the spontaneous onset of apoptosis in cultured rat ovarian granulosa cells and follicles by a tyrosine kinasedependent mechanism Molecular Endocrinology 6 1942-1950

Tsutsui T and Stabenfeldt GH (1993) Biology of ovarian cycles, pregnancy and pseudopregnancy in the dometic cat Journal of Reproduction and Fertility Supplement $4729-35$

Wasserman PM (1988) The mammalian ovum. In The Physiology of Reproduction, pp 69-102 Eds E Knobil and I Neill. Raven Press, New York 